\title{
K-AR DATED PALYNOFLORAS IN TASMANIA 1: EARLY OLIGOCENE, PROTEACIDITES TUBERCULATUS ZONE SEDIMENTS, WILMOT DAM, NORTHWESTERN TASMANIA
}

\author{
by M.K. Macphail \& R.S. Hill
}

(with two tables, five plates, three text-figures and an appendix)

Macphail, M.K. \& Hill, R.S., 1994 (30:vi): K-Ar dated palynofloras in Tasmania 1: Early Oligocene, Proteacidites tuberculatus Zone sediments, Wilmot Dam, northwestern Tasmania. Pap. Proc. R. Soc. Tasm. 128: 1-15.

https://doi.org/10.26749/rstpp.128.1 ISSN 0080-4703. Department of Geography, University of Newcastle,

Newcastle, New South Wales, Australia 2308 (MKM); Department of Plant Science, University of Tasmania, GPO Box 252C, Hobart, Tasmania, Australia 7001 (RSI-I).

Tertiary lake sediments at Wilnot Dam, northwestern Tasmania, are dated as Lower Proteacidites tuberculatus Zone, based on the palynological zonation developed for the Gippsland Basin in eastern Bass Strait. The age limits of Early-Middle Oligocene for this zone are in excellent agreement with a K/Ar date of $26.7 \mathrm{Ma}$ for basalts capping this deposit. Three new species are described: Tricolpites stylidioides, Mutisiapollis patersonii and Periporopollenites hexaporus. The first two appear to be the earliest records to date of Stylidiaceae and Mutisia (Asteraceae: tribe Mutisieae) respectively.

Key Words: palynofloras, Oligocene, Stylidiaceae, Mutisia, Trimeniaceae, Tasmania.

\section{INTRODUCTION}

The palynological zonation scheme developed for the Gippsland Basin by Stover \& Partridge (1973) has become widely used to date sediments elsewhere in Australia — to the extent that the individual zones, such as the Oligocenelate Early Miocene Proteacidites tuberculatus Zone, have become informal Stage names for the Australian Tertiary.

The criteria defining the zone boundaries, however, have had to be adapted from region to region to take account of known or suspected diachronism in the times of first appearance and extinction of zone "index" species. With few exceptions, this reflects variation in environmental forcing factors operating on the local to regional scale (see Macphail et al. 1994).

Widespread Tertiary volcanism has allowed a number of palynofloras in eastern Australia to be independently dated using Potassium/Argon (K/Ar), although in most situations this provides only a maximum or minimum age limit (e.g. Owen 1988, Pickett et al. 1990, Taylor et al. 1990, Macphail et al. 1991). Sutherland \& Wellman (1986) have reviewed $\mathrm{K} / \mathrm{Ar}$ dated volcanic rocks in Tasmania. This paper is the first in a series using a K/Ar dated palynoflora to assess the reliability of the Stover \& Partridge Gippsland Basin zonation as a method for dating non-marine sediments in Tasmania.

The sequence we analyse comes from the Wilmot Dam site in the Moina area of northwestern Tasmania (fig. 1). Here K/Ar dating confirms not only the P. tuberculatus Zone date for a buried channel deposit but also provides independent age control on glaciation of the adjacent upper Forth Valley during the late Paleogene (Macphail et al. 1993a). Three new fossil pollen species are described: Tricolpites stylidioides, Mutisiapollis patersonii and Periporopollenites hexaporus (appendix 1). Three other palynomorphs that may prove to be useful for identifying $P$. tuberculatus Zone palynofloras in Tasmania are illustrated: Tetrapollis campbellbrownit, Pesavis sp. cf. P. tagluensis and a distinctive but undescribed fungal fruiting body (pl. 1, M-P, see page 7).

\section{GEOLOGICAL SETTING}

Moina is located in an area of low, rugged interfluve ridges between the northwestern escarpment of the Central Plateau and Black Bluff Range. The region is geologically complex due to (1) partial stripping of subhorizontal Jurassic dolerites, exposing the underlying strongly folded and faulted preCarboniferous basements rocks, and (2) infilling of the incised drainage lines with basalt during the late Tertiary (Rawlings 1967). The latter is responsible for the preservation of Tertiary deposits at Wilmot Dam, located on the Wilmot River just below the junction of the Lea and Isis Rivers (fig. 1).

Here, Tertiary fluvio-lacustrine sediments accumulated in and spilt over from a trough bounded by sets of NNWand WNW-trending faults within the Ordovician Gordon Limestone and Moina Sandstone basement (fig. 1). Drilling by the Hydro-Electric Commission of Tasmania (HEC) suggests that movement along these faults created a system of lakes in which some $62 \mathrm{~m}$ of gravel, sands and clays accumulated during the Tertiary. Lacustrine sedimentation was followed by volcanic activity which buried the area under basaltic breccia and basalt flows (Paterson 1967, Rawlings 1967).

\section{SAMPLES}

The samples analysed in this study come from HEC drill hole 4558 drilled in 1965 by the HEC, close to the western margin of the trough where c. $26 \mathrm{~m}$ of Tertiary sediments underlie c. $20 \mathrm{~m}$ of volcanics (fig. 2).

Two samples of basalt were submitted to K. Henley, Amdel Ltd, South Australia: $43 \mathrm{ft}$ (13.1 m) [TSC58500], a porphyritic olivine basalt with small $(1-1.5 \mathrm{~mm})$ phenocrysts of olivine and plagioclase in a holocrystalline groundmass of plagioclase, pyroxene and Fe/Ti oxides; and $63 \mathrm{ft}(19.2 \mathrm{~m})$ [TSC58501], a rock similar to the above, except that much of the groundmass consisted of partly 


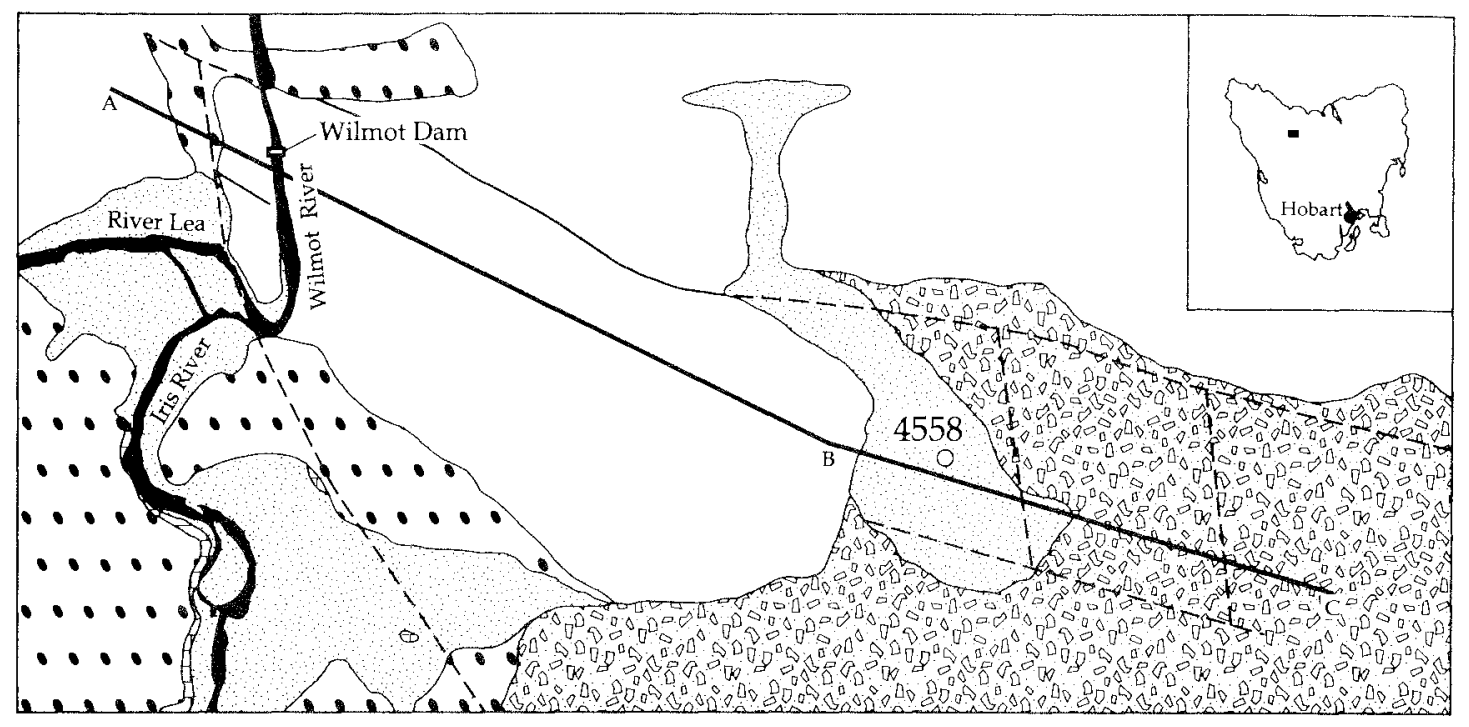

Cross section of buried

channel at Wilmot Dam site

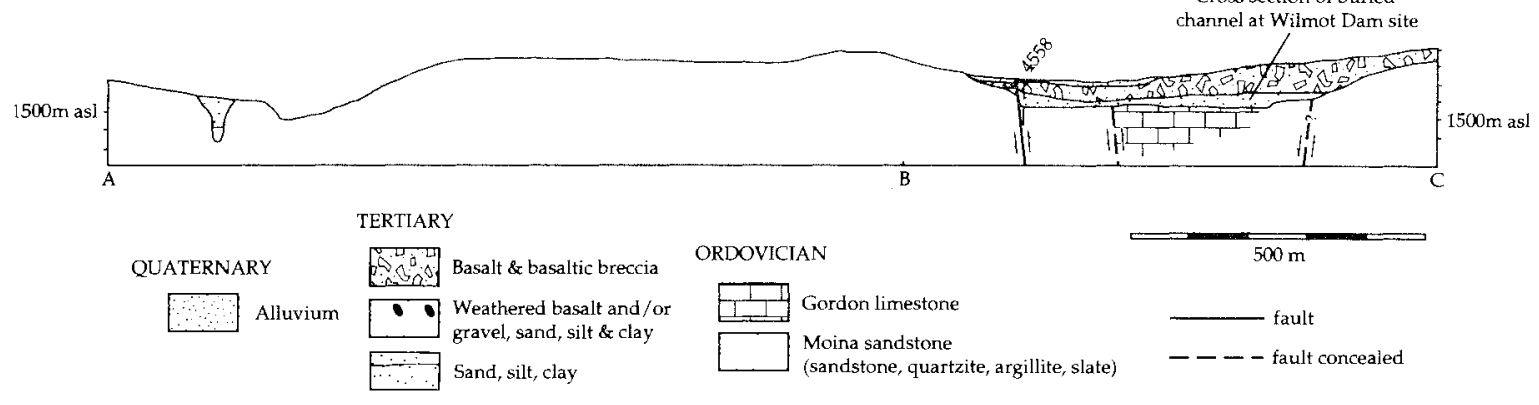

FIG. 1 - Simplified geology of the Wilmot Dam site (after Paterson 1967).

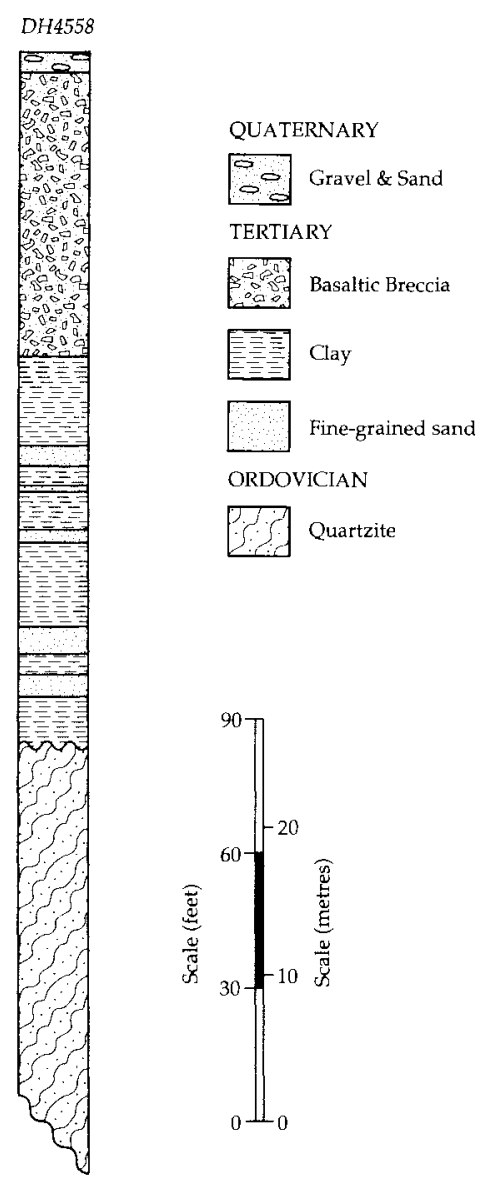

devitrified glass. Only the former was considered suitable for $\mathrm{K} / \mathrm{Ar}$ dating.

Two samples were processed for fossil palynomorphs by K. Weiss, Laola Pty Ltd, Perth: $70 \mathrm{ft}(21.3 \mathrm{~m})$, which yielded abundant, well-preserved fossil spores, pollen and cysts of a freshwater dinoflagellate, and $77.5 \mathrm{ft}(23.6 \mathrm{~m})$, which yielded moderate numbers of less well-preserved spores and pollen. Age diagnostic and a representative selection of other species are illustrated in plates 1-5: new species are described in appendix 1 .

\section{AGE DETERMINATIONS}

\section{Potassium/Argon}

Apart from patches of a yellow, weakly anisotropic alteration product making up less than $3-5 \%$ of the groundmass, the basalt sample at $13.1 \mathrm{~m}$ was assessed as fresh and, therefore, able to be dated with an acceptable level of reliability by K/Ar (Amdel Report G6809/93).

Potassium and argon analyses and calculated age are given in table 1. The date of $26.7 \mathrm{Ma}$ approximates to the Middle/ Late Oligocene, based on currently accepted boundaries of 35.4 Ma and 23.3 Ma for the Epoch as a whole (Harland et al. 1990). 


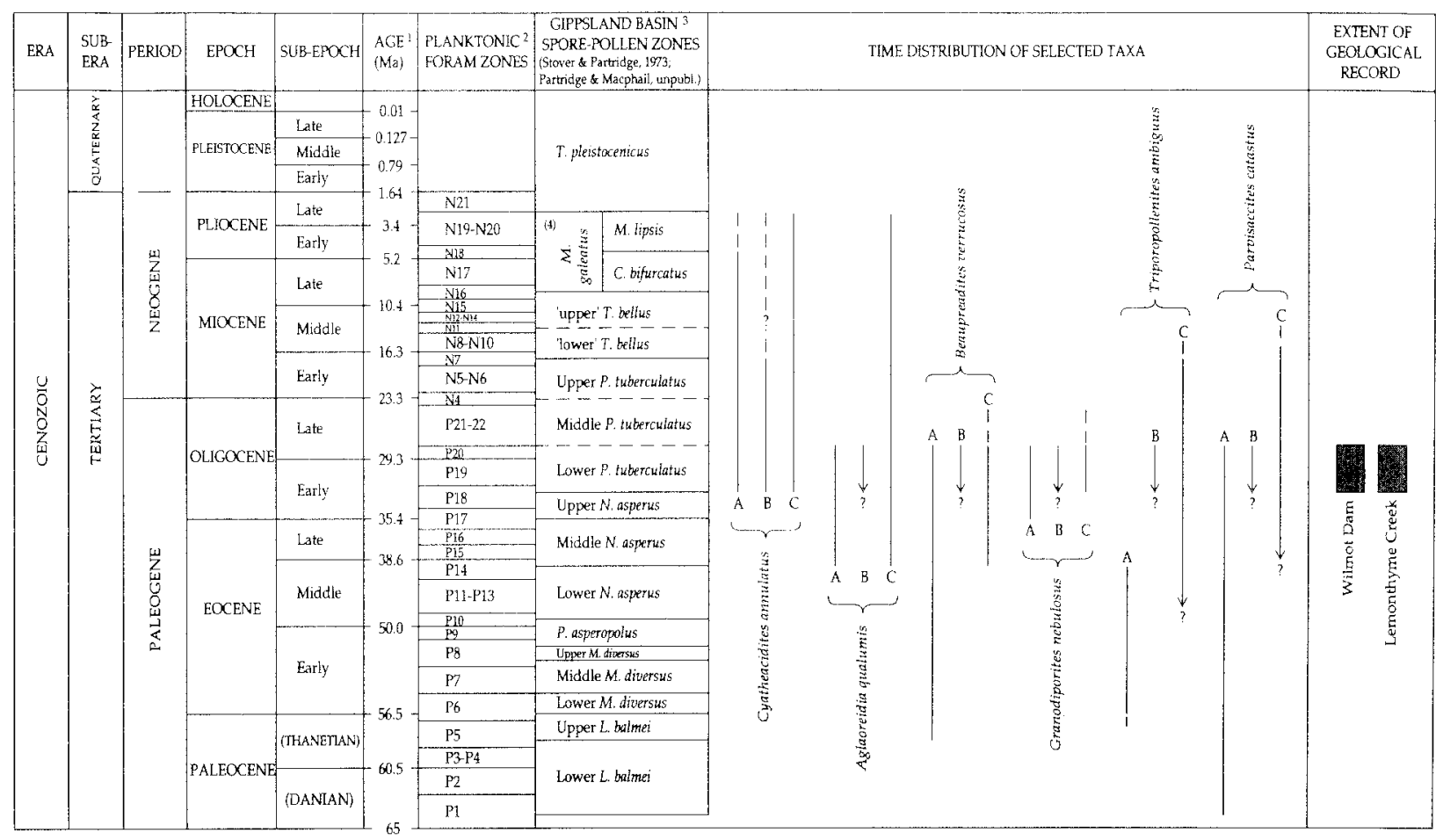

FIG. 3 - Time distribution of age-diagnostic taxa in (A) Gippsland Basin, (B) northwestern Tasmania and (C) Murray Basin, southeastern Australia, shown against the Cenozoic time scale of Harland et al. (1990). 1, 2 = calibration of Stage boundaries and correlation of planktonic foraminiferal biozones based on Harland et al. (1990). 3 = correlation of Gippsland Basin palynological zones against planktonic foraminiferal biozones prepared by A.D. Partridge (8th May 1993). $4=$ Murray Basin (Macphail \&o Truswell, pers. obs.).

\section{Palynostratigraphy}

The stratigraphic distribution of fossil spores and pollen in samples at $21.3 \mathrm{~m}$ and $23.6 \mathrm{~m}$ is given in table 2 . The time distributions of key taxa are shown in figure 3 .

Occurrences of Cyatheacidites annulatus in both samples provide a reliable lower age limit of Early Oligocene, Proteacidites tuberculatus Zone age for sediments near the top of the lacustrine infill (Stover \& Partridge 1973). The upper age limit is Lower $P$. tuberculatus Zone, based on multiple occurrences of Aglaoreidia qualumis, Beaupreaidites verrucosus, Granodiporites nebulosus, Triporopollenites ambiguus and Parvisaccites catastus (pl. 1, A-L).

Species which first appear in the Gippsland Basin within the Early Miocene, Upper $P$. tuberculatus Zone, e.g. Acaciapollenites myriosporites, and overlying late Early-Late Miocene, Triporopollenites bellus Zone, e.g. Canthiumidites (al. Triporopollenites) bellus, Symplocoipollenites austellus and Rugulatisporites cowrensis, are absent.

TABLE 1

K/Ar analyses

\begin{tabular}{lcccc}
\hline Sample & $\% \mathrm{~K}$ & ${ }^{40} \mathrm{Ar}^{*}$ & ${ }^{40} \mathrm{Ar}^{*} /$ & Age† \\
& & $\times 10^{-11}$ moles $\left./ \mathrm{g}\right)$ & ${ }^{40} \mathrm{Ar}_{\text {total }}$ & \\
$13.1 \mathrm{~m}$ & 0.7348 & 3.4618 & 0.634 & $26.7 \pm 0.3$ \\
\hline
\end{tabular}

* Denotes radiogenic ${ }^{40} \mathrm{Ar}$.

$\uparrow$ Age in Ma with error limits given for the analytical uncertainty at one standard deviation.

\section{DISCUSSION}

The lake sediments are older than the dated basalt and, therefore, all or part of the Lower $P$. tuberculatus Zone in northwestern Tasmania is older than 26.7 Ma.

As for other sites in northwestern Tasmania (Hill \& Macphail 1983, Macphail et al. 1991), the Wilmot Dam palynofloras include a number of species whose time ranges do not overlap in the Gippsland Basin. Examples are: (1) Chenopodipollis chenopodiaceoides and $(21.3 \mathrm{~m})$ Foveotriletes lacunosus, two of the species whose first appearance defines the lower boundary of the Middle $P$. tuberculatus Zone, and (2) Tricolpites simatus and $(23.6 \mathrm{~m})$ Triporopollenites ambiguus, species which range no higher than the Late Eocene, Middle Nothofagidites asperus Zone. 
TABLE 2

Stratigraphic distribution of fossil spores and pollen at Wilmot Dam and Lemonthyme Creek

\begin{tabular}{|c|c|c|c|c|}
\hline \multirow[t]{2}{*}{ Fossil species } & Wilmot Dam DDH 4558 & \multicolumn{2}{|c|}{ Lemonthyme DDH 5825} & \multirow[t]{2}{*}{ Modern analogue } \\
\hline & $21.3 \mathrm{~m}$ & $23.6 \mathrm{~m}$ & $20.1-45.3 m$ & \\
\hline
\end{tabular}

(a) Algae

Pseudoschizea circula

Saeprodinium sp.

(b) Fungi

Pesavis cf. tagluensis

Unidentified sporae dispersae

(c) Ferns \& Fern Allies

Baculatisporites disconformis

Bryosporis anisopolaris

Cyatheacidites annulatus

Cyathidites australis

Cyathidites paleospora

Cyathidites splendens

Dictyophyllidites arcuatus

Foveotriletes balteus

Foveotriletes lacunosus

Foveotriletes palaequetrus

Gleicheniidites spp.

Herkosporites elliotii

Ischyosporites-Triletes complex

Laevigatosporites spp.

Latrobosporites crassus

Latrobosporites marginis

Matonisporites omamentalis

Osmundacites sp.

Peromonolites densus

P. vellosus

Polypodiisporites histiopteroides

Reticuloidaesporites spp.

Retitriletes australoclavatidites

Rugulatisporites mallatus

Stereisporites australis

Verrucosisporites cristatus

Verrucosisporites kopukuensis

(d) Gymnosperms

Araucariacites australis

Cupressaceae-Taxodiaceae

Dacrycarpites australiensis

Dilwynites granulatus

Lygistepollenites florinit

Microalatidites paleogenicus

Microcachrydites antarcticus

Parvisaccites catastus

Phyllocladidites mawsonii

Podocarpidites spp.

Podosporites erugatus

P. parvus

P. microsaccatus

Trichotomosulcites subgranulosus

(e) Angiosperms

Aglaoreidia qualumis

Banksieaeidites elongatus

Beaupreaidites elegansiformis

B. verrucosus

Chenopodipollis chenopodiaceoides

Clavatipollenites glarius

Cupanieidites orthoteichus

Cyperaceaepollis neogenicus

Dodonaea triquetra-type

Droseraceae

Dryadopollenites retequetrus

Ericipites crassiexinus

E. scabratus

Gothanipollis of. bassensis

$G$. cf. gothanii

cont. indet. soil? algae

Freshwater dinoflagellate

indet. fungus

indet. fungus

Liverworts

Mosses

Lophosoria quadrapinnata

ground ferns

Cyatheaceae

Acrostichum?

Gleicheniaceae

Lycopodiaceae

Lycopodium varium-type

Lycopodium australium-type

Gleicheniaceae

Lycopodium deuterodensum-type

indet. lycopsids

Blechnaceae?

inder. lycopsid

Lycopodium laterale-type

Dicksoniaceae

Osmundaceae?

Blechnaceae?

Blechnaceae?

Histiopteris

inder. fern

Lycopodiaceae

Culcita dubia-type

Sphagnum

inder. lycopsid?

indet. lycopsid?

Araucariaceac

Cupressaceae-Taxodiaceae

Dacrycarpus

Araucariaccae

Dacrydium Group B spp.

Phyllocladus

Microcachrys

Dacrydium bidwillii-rype

Lagarostrobos franklinii

Podocarpus/Dacrydium

Microstrobos

Microcachrys?

indet. Podocarpaceae

indet. Podocarpaceae

Sparganiaceae/Typhaceae

Banksia

Beauprea

Beauprea

Chenopodiaceae

Ascarina

Sapindaceae (Cupanieae)

Cyperaceae

Dodonaea triquetra

Droseraceae

inder. angiosperm

Ericales

Ericales

Loranthaceac

Loranchaceae 


\begin{tabular}{|c|c|c|c|c|}
\hline \multirow[t]{2}{*}{ Fossil species } & \multirow{2}{*}{$\frac{\text { Wilmor Dam DDH } 4558}{21.3 \mathrm{~m}}$} & \multicolumn{2}{|c|}{ Lemonthyme DDH 5825} & \multirow[t]{2}{*}{ Modern analogue } \\
\hline & & $23.6 \mathrm{~m}$ & $20.1-45.3 \mathrm{~m}$ & \\
\hline G.perplexus & . & - & + & Loranthaceae \\
\hline Granodiporites nebulosus & + & + & + & Embothrium \\
\hline Gyropollis psilatus & & - & + & Gyrostemonaceae \\
\hline $\begin{array}{l}\text { Haloragacidites harrisit- } \\
\text { Casuarinidites cainozoicus }\end{array}$ & 1 & 4 & 3 & Casuarinaceae \\
\hline Ilexpollenites anguloclavatus & & + & + & Ilex \\
\hline Liliacidites lanceolatus & + & + & + & Liliaceae \\
\hline Malvacipollis spinyspora & + & + & + & Micrantheum \\
\hline M. subtilis & + & + & + & Austrobuxus \\
\hline Margocolporites cf. scaboratus & + & ـ & _. & indet. angiosperm \\
\hline Milfordia homeopunctatus & + & - & - & Restionaceae \\
\hline M. hypolaenioides & + & + & & Restionaceae \\
\hline Mutisiapollis patersonii & + & + & + & Mutisia \\
\hline Myrtaceidites parvus-mesonesus & $\mathrm{l}$ & + & + & Myrtaceae (not Eucalyptus) \\
\hline Nothofagidites asperus & 1 & + & 3 & Nothofagus (Lophozonia) \\
\hline N. brachyspinulosus & 5 & 5 & 4 & Nothofagus (Fuscospora) \\
\hline N. deminutus-vansteenisii & + & + & 2 & Nothofagus (Brasssopora) \\
\hline N. emarcidus-heterus & 37 & 24 & 29 & Nothofagus (Brassospora) \\
\hline N. falcatus & + & + & + & Nothofagus (Brassospora) \\
\hline N. flemingii & 2 & 1 & 6 & Nothofagus (Nothofagus) \\
\hline N. goniatus & - & . & + & Nothofagus (Lophozonia?) \\
\hline Palaeocoprosmadites zelandiae & - & + & - & Coprosma/Opercularia \\
\hline pentacolporate sp. & + & + & - & Meliaceae? \\
\hline Periporopollenites demarcatus & + & - & + & Trimeniaceae? \\
\hline P. hexaporus & + & + & + & Trimeniaceae? \\
\hline P. vesicus & 1 & + & + & Trimeniaceae? \\
\hline Polyorificites oblatus & + & - & + & indet. angiosperm \\
\hline Proteacidites adenanthoides & - & - & + & Adenanthos? \\
\hline P. annularis & - & - & + & Xylomelum \\
\hline P. obscurus & + & + & + & Agastachys-type \\
\hline P. Latrobensis & + & - & + & indet. Proteaceae \\
\hline P. pseudomoides & + & . & + & indet. Proteaceae \\
\hline P. reticuloscabratus & - & - & + & Gevuina/Hicksbeachia \\
\hline P. scaboratus & + & + & + & Macadamia-type \\
\hline Proteacidites spp. & 3 & 4 & 3 & Proteaceae \\
\hline Pseudowinterapollis cranwellae & + & - & + & Tasmannia \\
\hline Quintiniapollis psilatispora & + & - & + & Quintinia \\
\hline Retistephanocolpites sp. aff. Callitriche & - & + & - & Callitichaceae \\
\hline Rhoipites sp. cf. Muehlenbeckia & + & + & - & Muehlenbeckia \\
\hline Sapotaceoidaepollenites latizonatus & + & + & + & Sapotaceae \\
\hline S. rotundus & - & - & + & Sapotaceae \\
\hline Sparganiaceaepollenites sphericus & + & + & - & Sparganiaceae \\
\hline Stephanocolpites oblatus & + & + & - & Haloragodendron \\
\hline S. sphericus & - & - & + & indet. \\
\hline Striasyncolpites laxus & - & - & + & Menyanthaceae \\
\hline Tetracolporites palynius & + & + & - & Ixerba? \\
\hline Tricolpites reticulatus & + & - & + & Gunnera \\
\hline T. simatus & + & + & + & Loranthaceae \\
\hline T. stylidioides & + & + & + & Stylidiacexe \\
\hline T. trioblatus & + & + & + & Scrophulariaceae \\
\hline Tricolpites spp. & + & + & + & indet. angiosperms \\
\hline Tricolporites cf. adelaidensis & + & + & + & indet, angiosperm \\
\hline Tricolporites leuros & - & - & + & inder. angiosperm \\
\hline T. microreticulatus & + & + & - & indet. angiosperm \\
\hline T. paenestriatus & + & - & - & indet. angiosperm \\
\hline Tricolporites spp. & 3 & + & 3 & indet. angiosperms \\
\hline Tetrapollis campbellbrownii & + & - & - & Haloragaceae? \\
\hline Triporopollenites ambiguus & - & + & + & Telopea - type \\
\hline T. sp. cf. T. chnosus & + & + & + & indet. Proteaceae \\
\hline Pollen sum & 492 & 355 & 393 & \\
\hline
\end{tabular}

Relative abundance values expressed as a percentage of the total identifiable pollen and spore count (excluding algae, fungi and liverworts). Percentages less than $1 \%$ are given as + . 
This almost certainly reflects differences in topography, local climate and depositional environment between the deeply incised, moderate to high plateaux, characteristic of northwestern Tasmania, and the Gippsland Basin, which was a low-lying coastal plain, backed by extensive freshwater peat swamps in the Latrobe Valley Depression (Sluiter \& Kershaw 1982, Holdgate \& Sluiter 1991) and, as now, open to the Tasman Sea to the southeast.

Nevertheless, the palynological age determination of Lower $P$. tuberculatus Zone is in excellent agreement with both the K/Ar date of 26.7 Ma and Stover \& Partridge's conclusion (1973: 243-244) that the top of the Middle $P$. tuberculatus Zone approximates to the Oligocene-Miocene boundary. We conclude, therefore, that the criteria proposed by Stover \& Partridge (1973) are a reliable method for dating strata of Oligocene, P. tuberculatus Zone age in Tasmania. Some uncertainty still exists regarding strata of Early Miocene, $P$. tuberculatus Zone age, since the earliest record to date of any index species of the overlying $T$. bellus Zone is Late Pliocene - Symplocoipollenites austellus at Linda Valley, western Tasmania (Macphail et al., in prep.).

The Wilmot Dam palynofloras are virtually identical in composition to fossil assemblages recovered from a $34 \mathrm{~m}$ thick sequence of laminated clays and silts overlying a tillite at Lemonthyme Creek in the adjoining Forth Valley (Paterson et al. 1967). Age-diagnostic species conmon to both deposits include Cyatheacidites annulatus, Beaupreaidites verrucosus, Granodiporites nebulosus, Parvisaccites catastus and Triporopollenites ambiguus (table 2).

Reinforcing the impression that the deposits are coeval are occurrences of two new species (appendix 1) that appear to be restricted to $P$. tuberculatus Zone palynofloras in Tasmania: Periporopollenites hexaporus and Mutisiapollis patersonii. Other distinctive shared taxa include Droseraceae and Tricolpites stylidioides (pls 1,2).

Basalts associated with the Lemonthyme deposit are unsuitable for $\mathrm{K} / \mathrm{Ar}$ dating and, based on spore-pollen evidence alone, Macphail et al. (1993a) concluded that the tillite was most probably Early Oligocene and highly unlikely to be younger than Late Oligocene. This makes the (local) glaciation responsible for deposition of the tillite the oldest recorded to date, outside of Antarctica during the Cenozoic. The Early-Middle Oligocene date for the Wilmot Dam palynosequence supports and strengthens this conclusion.

The latest Eocene-earliest Oligocene is widely seen as a critical period in the history of Cenozoic global cooling, and a significant number of tree and shrub taxa that had been typical of Eocene megatherm-mesotherm rainforest in the Bass Strait region did not survive into Oligocene time (Macphail et al. 1994). Nevertheless, it is equally clear from sites such as Wilmot Dam and Lemonthyme Creek that the Tasmanian flora continued to be enriched by new species, either through continued differentiation of the original Gondwanic stock in Australia or through long-distance dispersal, probably via Antarctica.

It is tempting to speculate that the former (autochthonous) group includes Periporopollenites hexaporus, possibly derived from the same Trimeniaceaen stock as $P$. demarcatus, which first apppears in southeastern Australia during the Maastrichtian. The first appearance of Mutisiapollis patersonit and Tricolpites stylidioides are more likely to be due to longdistance dispersal via Antarctica for two reasons. Firstly, both taxa include modern representatives in South America (Mabberley 1989). Secondly, palaeogeographic evidence (Veevers et al. 1991) shows that, during the Early Oligocene, Tasmania was a mountainous peninsula at about latitude $55^{\circ}-63^{\circ}$, separated from Antarctica by the circum-Antarctic Ocean. Both appear to be the oldest fossil records to date of these taxa (compare Muller 1981).

\section{ACKNOWLEDGEMENTS}

We thank P. Augustinus, University of Tasmania, and $S$. Forsyth, Department of Mines and Energy, who provided the samples analysed in this study, and A.D. Partridge for permission to incorporate in figure 3 a simplified version of his unpublished correlation of the Gippsland Basin palynological zones against the Harland et al. (1990) Cenozoic time scale. This research was supported by a grant from the Australian Research Council.

Age-diagnostic taxa. All photomicrographs $\times 1250$ unless otherwise stated. Scale bar $A=25 \mu \mathrm{m}$; scale bar $B=50 \mu \mathrm{m}$. Cyatheacidites annulatus Cookson, 1947, $\times 788$. (A) Lemonthyme DH 5825 at $31.1 \mathrm{~m}$, P. tuberculatus Zone; (B) Lemonthyme DH 5802 at $46 \mathrm{~m}$, P. tuberculatus Zone; (C) Lemonthyme DH 5825 at $30.8 \mathrm{~m}$, P. tuberculatus Zone; (D) Lemonthyme DH 5825 at $24.7 \mathrm{~m}$, P. tuberculatus Zone.

Parvisaccites catastus Stover \& Partridge, 1973. (E) Wilmot Dam DH 4558 at $21.3 \mathrm{~m}$, P. tuberculatus Zone. Granodiporites nebulosus Stover \& Partridge, 1973. (F) Wilmot Dam DH 4558 at 23.6 m, P. tuberculatus Zone; $(G)$ as above, phase contrast showing scattered granulae.

Triporopollenites ambiguus Stover of Partridge, 1973. (H) Lemonthyme DH 5825 at $45.3 \mathrm{~m}$, P. tuberculatus Zone. Beaupreaidites verrucosus Cookson, 1950. (I) Wilmot Dam DH 4558 at 23.6 m, P. tuberculatus Zone; (J) Lemonthyme DH 5825 at $30.1 \mathrm{~m}$. P. tuberculatus Zone phase contrast; $(K)$ Lemonthyme DH 5825 at $39.9 \mathrm{~m}$, P. tuberculatus Zone phase contrast. Aglaoreidia qualumis Stover \& Partridge, 1973. (L) Wilmot Dam DH 4558 at $23.6 \mathrm{~m}$, P. tuberculatus Zone.

Tetrapollis campbellbrownii Macphail of. Truswell, 1993. (M) Wilmot Dam DH 4558 at $21.3 \mathrm{~m}$, P. tuberculatus Zone; (N) as above, phase contrast showing grooved nexine around pores.

Pesavis sp. of. P. tagluensis (Elsik \& Jansonius, 1974); ×788; (O) Lemonthyme DH 5825 at $29.3 \mathrm{~m}$, P. tuberculatus Zone; unidentified Fungi Sporae Dispersae; $\times$ 788; (P) Lemonthyme DH 5825 at $31.1 \mathrm{~m}$, P. tuberculatus Zone. 

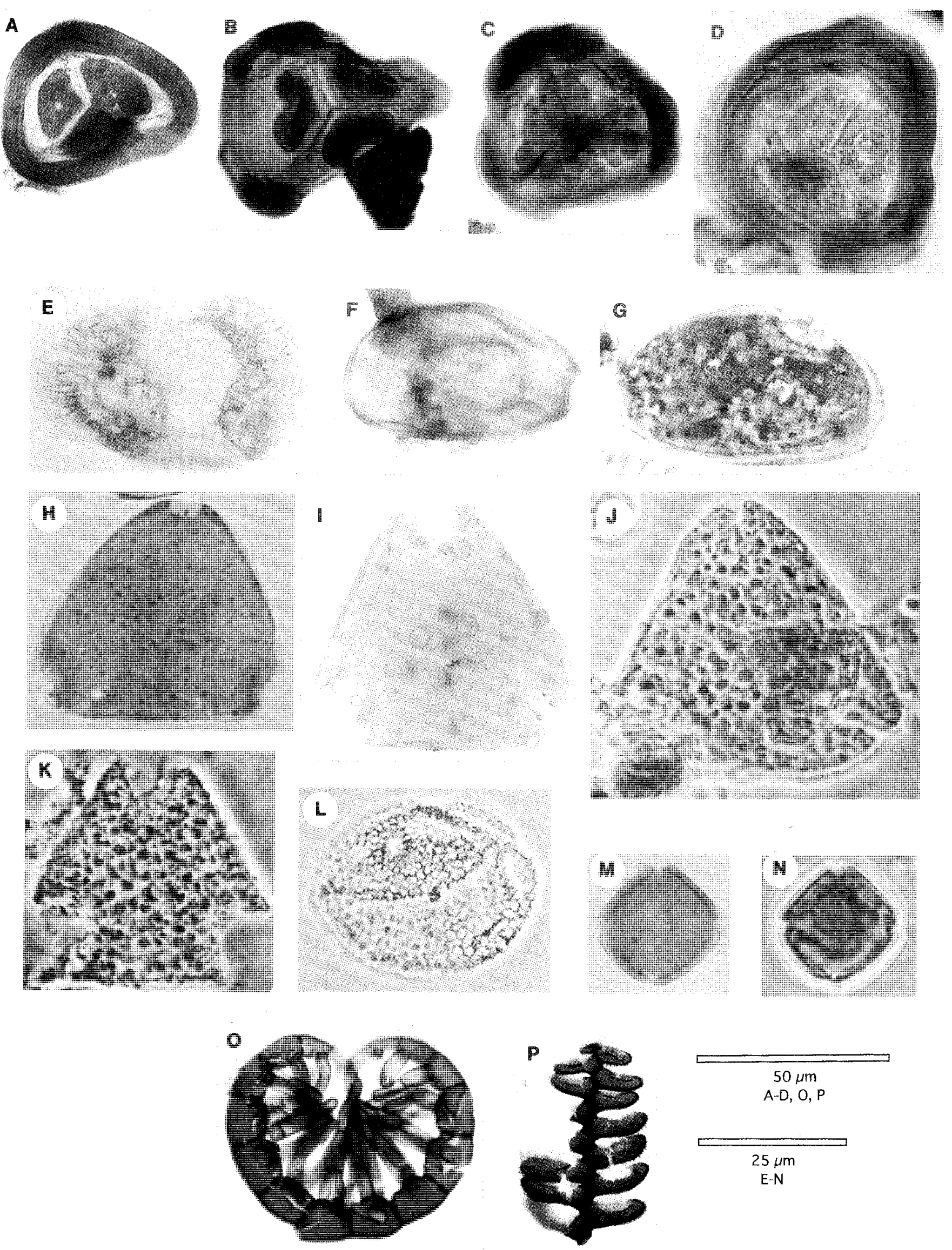


\section{REFERENCES}

Elsik, W.C. \& Jansonius, J., 1974: New genera of Paleogene fungal spores. Can. J. Bot. 52: 953-958.

ERdTMAn, G., 1966: POLLEN MORPHOLOGY AND PLANT TAXONOMY: ANGIOSPERMS. Hafner Publishing Co., New York: 553pp.

HarL.AND, W.B. \& FIVE CO-AUTHORS, 1990: A GEOLOGIC TIME SCALE 1989. Cambridge University Press, Cambridge: $263 \mathrm{pp}$.

Heusser, C.J., 1971: POLLEN AND SPORES OF CHILE: University of Arizona Press, Tucson: $167 \mathrm{pp}$.

HILL, R.S. \& MacPHall, M.K., 1983: Reconstruction of the Oligocene vegetation at Pioneer, north-east Tasmania. Alcheringa 7: 281-289.

Holdgate, G.R. \& Siutike, I.R., 199i: Oligocene-Miocene marine incursions in the Latrobe Valley depression, onshore Gippsland Basin: evidence, facies relationships and chronology. Geol. Soc. Aust. Spec. Pubi. 18: 137-157.

Mabberly, D.J., 1989: THE PLANT BOOK. Cambridge University Press, Cambridge: $706 \mathrm{pp}$.

Macphail, M.K. \& Truswell, E.M., 1993: Appendix 1. Taxonomic, phytogeographic and biostratigraphic notes on selected species. AGSO f. Aust. Geol. Geophys. 14: 61-63.

Macphall, M.K., Hill, R.S., Forsyth, S.M. \& Well.s, P.M., 1991: A Late Oligocene-Early Miocene cool climate flora in Tasmania. Alcheringa 15:87-106.

Macphall, M.K. , Colhoun, E.A., KilerNan, K. \& Hannan, D., 1993a: Glacial climates in the Antarctic region during the Late Paleogene: evidence from northwest Tasmania, Australia. Geology 21: 145-148.

Macphail, M.K., Jordan, G.J. \& Hill, R.S., 1993b: Key periods in the evolution of the Cenozoic flora and vegetation of Tasmania 1: the Early-Middle Pleistocene. Aust. J. Bot. 41: 673-707.

Macphale, M.K., Fitzsimons, S. \& Colhoun, E.A., in prep.: Key periods in the evolution of the Cenozoic flora and vegetation of Tasmania 2: the Late Pliocene.

Macphail, M.K., Alley, N., Trusweil, E.M. \& Sluiter, I.R. 1994: Early Tertiary vegetation: evidence from spores and pollen. In Hill, R.S. (Ed.): HISTORY OF THE AUSTRALIAN VEGETATION: CRETACEOUS TO RECENT. Cambridge University Press, Cambridge: 189 261.

Muller, J., 1981: Fossil pollen records of extant angiosperms. Bot. Rev. 47: 1-142.
OWH, J.A.K., 1988: Miocene palynomorph assemblages from Kiandra, New Sourh Wales. Alcheringa 12: 269-297.

Partrifcie, A.D., 1978: Palynology of the Late Tertiary sequence at Site 356, Leg 40, Deep Sea Drilling Project. Initial Rep. Deep Sea Drilling Proj. 40: 953-961.

PATtRson, S.J., 1967: Tertiary deep lead deposits in the Moina area. Pap. Proc. R. Soc. Tasm. 101: 251-260

Pathrson, S.J., Duigan, S.L. \& Joplin, G.A., 1967: Notes on the Pleistocene deposits at Lenonthyme Creek in the Forth Valley. Pap. Proc. R. Soc. Tasm. 101: 221-225.

PickeTT, J.W. \& HVE (O)-ALTHORs, 1990: A stratigraphic evaluarion of Ettinhausen's New England Terriary plant localities. Aust. J. Earth Sci. 37: 293-303.

Rawtings, G.E., 1967: Sub-basaltic sediments and metasediments of the Mersey-Forth area. Pap. Proc. R. Soc. Tasm. 101: $267-270$.

Skvarta, J.I., Turnek, B.I., Pathi, V.C. \& Tomb, A.S., 1977 : Pollen morphology in the Compositae and morphologicaliy related families. In Heywood, V.H., Harbourne, J.B. \& 'Turner, B.L. (Eds): THE BIOLOGY AND CHEMISTRY OF THE COMPOSITAE. Academic Press, London: 141-241.

SI.UITER, 1.R. \& KerSHAW, A.P., 1982: The nature of Late Tertiary vegetation in Australia. Aicheringa 6: 211-222.

STIX, E., 1960: Pollenmorphologische untersuchungen and Compositae. Grana palynol. 2: 41-114

STover, L.E. \& Partridgil, A.D., 1973: Tertiary and Late Cretaceous spores and pollen from the Gippsland Basin, southeastern Australia. Proc. R. Soc. Vict. 85: 237-286.

Suthert.anid, F.L. \& Weliman, P., 1986: Potassium-Argon ages of Tertiary volcanic rocks, Tasmania. Pap. Proc. R. Soc. Tasm. 120: 77-86.

Taylor, G., Truswell, E.M., McQueen, K.G. \& Brown, M.C., 1990: Early-Tertiary palaeogeography, landform evolution and palaeoclimates of the Southern Monaro, N.S.W., Australia. Palaeogeogr., Palaeoclimatol. Palaeoecol. 78: 109-134

Thompson, P.W. \& Pllug, H., 1953: Pollen und sporen des mitteleuropäischen Tertiärs. Palaentol. graphica Abt B, 94: $1-138$

Truswet., E.M. \& MarChaNF, N.G., 1986: Early Tertiary pollen of probable Droseracean affinity from Central Australia. Spec. Pap. Palaeontol. 35: 163-178.

Vefvers, J.J., Powill, C.McA. \& Roots, S.R., 1991: Review of seafloor spreading around Australia. 1. Synthesis of patterns of spreading. Aust. J. Earth Sci. 38: 373-389.

(accepted 1 June 1993)

PLATE 2

New species. All photomicrographs $\times 1250$ unless otherwise stated. Scale bar $A=25 \mu \mathrm{m}$; scale bar $B=50 \mu \mathrm{m}$.

Tricolpites stylidioides $n$. sp. (A-D) Holotype at three focal planes; equatorial view; figure 4 phase contrast - Lemonthyme DH 5825 at $36.6 \mathrm{~m}$. P. tuberculatus Zone; (E) paratype; polar view of unusually small specimen - Lemonthyme DH 5825 at $36.6 \mathrm{~m}$, P. tuberculatus Zone; $(F)$ paratype; equatorial view - Lemonthyme DH 5825 at $31.1 \mathrm{~m}$. P. tuberculatus Zone; $(G)$ specimen showing mesocolpial thickening of nexine - Lemonthyme DH 5825 at $31.1 \mathrm{~m}$, P. tuberculatus Zone; $(H)$ specimen showing irregular margins of colpi - Wilmot Dam DH 4558 at $23.6 \mathrm{~m}$. P. tuberculatus Zone; (I) specimen showing strongly thickened nexine at poles - Lemonthyme DH 5825 at $31.1 \mathrm{~m}$. P. tuberculatus Zone; (J) unusually large oblate specimen (crushed) - Lemonthyme DH 5802 at $46 \mathrm{~m}$, P. tuberculatus Zone.

Mutisiapollis patersonii $n$. sp. $(K-N)$ Holotype at three focal planes; equatorial view; figure 14 phase contrast - Lemonthyme DH 5825 at $30.8 \mathrm{~m}$. P. tuberculatus Zone; (O-P) oblique polar view; figure I4 phase contrast showing puncto-reticulate tectum - Lemonthyme DH 5825 at $36.6 \mathrm{~m}$. P. tuberculatus Zone; (Q-R) equatorial view at two focal planes of a grain showing an undulating. micro-echinate tectum in which the puncta have joined to form fossulae; (S) equatorial view of small specimen with unusually well-developed micro-echinate sculpture - Lemonthyme DH 5825 at $33.5 \mathrm{~m}$, P. tuberculatus Zone; (T) Wilmot Dam DH 4558 at $21.3 \mathrm{~m}$, P. tuberculatus Zone; (U) Lemonthyme DH 5825 at $39.9 \mathrm{~m}$, P. tuberculatus Zone. 

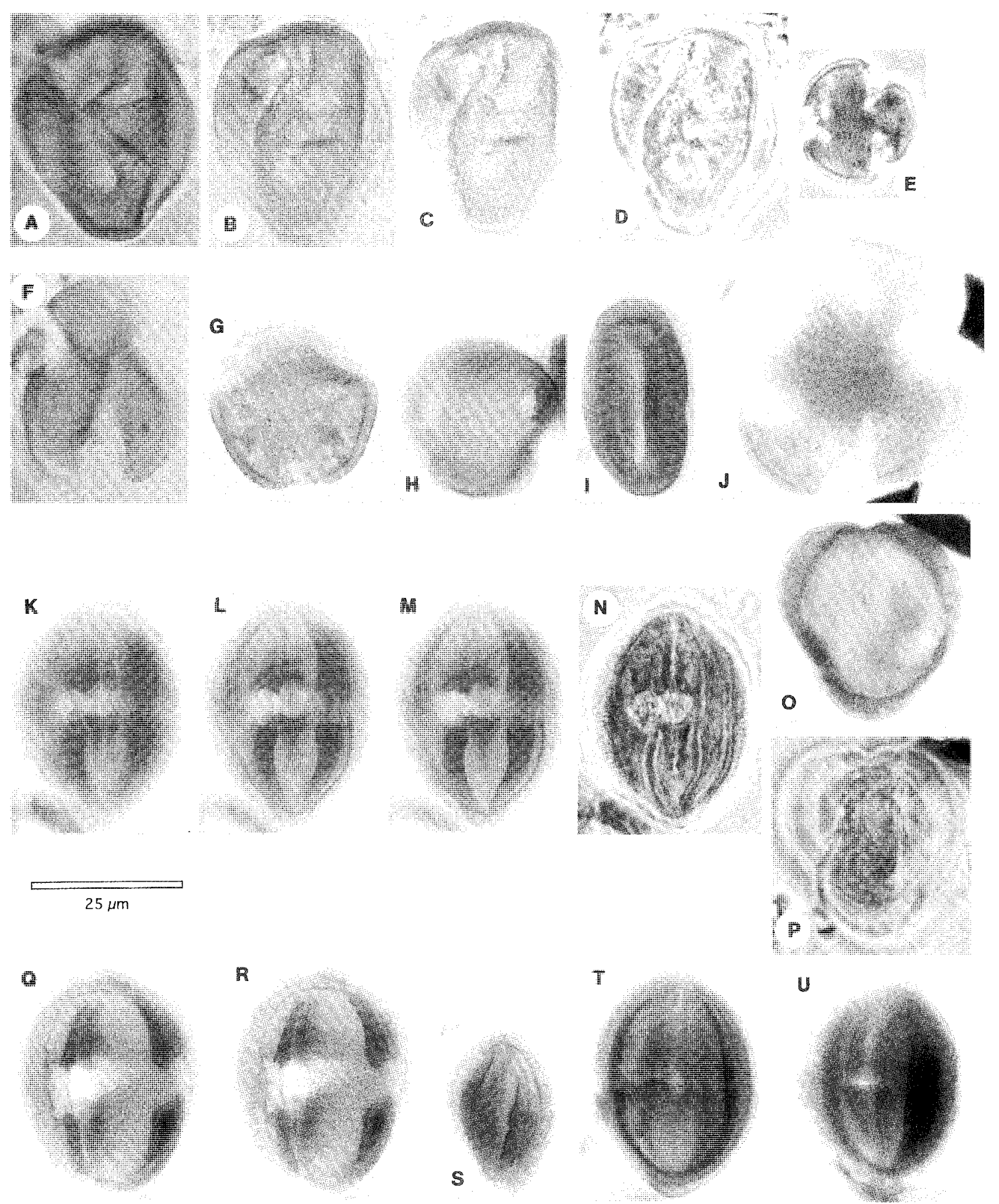


\section{APPENDIX 1}

Although the Wilmot Dam and Lemonthyme Creek palynofloras are dominated by long-ranging taxa, chiefly Nothofagus and Podocarpaceae, they include a number of rare to uncommon types that, to date, have only been recorded in Tasmania, e.g. Mutisiapollis paterionii n.sp. and Periporopollenites hexaporus n.sp. Others are the oldest records anywhere, e.g. Tricolpites stylidioides n. sp., or significantly extend the known geographic range of the taxon, e.g. Tetrapollis campbellbrownii Macphail \& Truswell, 1993.

\section{NEW SPECIES}

\section{Tricolpate Pollen}

GENUS Tricolpites Cookson, 1947 ex Couper, 1953

TYPE SPECIES Tricolpites reticulatus Cookson, 1947 (subsequent designation by Couper, 1953)

\section{Tricolpites stylidioides n.sp. (pI. 2, A-J)}

HOLOTYPE. Slide SB W-001, stored in the Department of Plant Science, University of Tasmania. England Finder co-ordinates R43(2). Paratypes at O40(4), R45(1), T37(0), T43(2), U41(0) and $\mathrm{W} 67(0)$ on the same slide.

TYPE LOCALITY. HEC drillhole 5825, Lemonthyme Creek ( $\left.41^{\circ} 37^{\prime} \mathrm{S}, 146^{\circ} 09^{\prime} \mathrm{E}\right)$, at $136.0 \mathrm{ft}(41.45 \mathrm{~m})$, Early Oligocene.

DERIVATION OF NAME. From the presumed botanical affinity with the Stylidiaceae.

DIAGNOSIS. Monad, isopolar, radiosymmetric, stephanocolpate, apertures three, less frequently four, elongate, usually gaping with ragged margins, subprolate-suboblate, usually distorted (compressed oval), crushed grains oblare; amb subcircular; exine $1-1.5 \mu \mathrm{m}$ at equator increasing to $3 \mu \mathrm{m}$ at pole, nexine, markedly thicker than sexine, thickening across poles, intectate, apiculate, apiculae short and narrow, $<0.5 \mu \mathrm{m}$ high, scattered at regular intervals c. $1 \mu \mathrm{m}$ apart.

DIMENSIONS. Polar diameter 25-(28)-40 $\mu \mathrm{m}$, eighe specimens measured; equatorial diameter $20-(31)-45 \mu \mathrm{m}$, ten specimens measured.

\section{BOTANICAL AFFINITY. ForsteralPhyllachne (Stylidiaceae).}

KNOWN DISTRIBUTION. Tasmania - Early Oligocene to present; Gippsland Basin - earliest Oligocene to terminal Pliocene; central-west Murray Basin — Oligocene to Late Miocene.

DISCUSSION. The type closely resembles pollen of the Stylidiaceae, in particular Fostera Linn. f., a very small genus of perennial herbs now confined to montane-subalpine habitats in Tasmania, New Zealand and Fuegia. Tetracolpate, suboblate specimens approximate to the type produced by Phyllachne J.R. et G. Forst. The only widespread lowland member of the family in Australia, Stylidium graminifolium Swarcz, produces strongly oblate pollen with five to six gaping colpi with rounded apices, a type not recorded earlier than Late Pliocene sediments in Tasmania.

Specimens from northwestern Tasmania are the oldest fossil pollen recotd of the family to date. The presence of Tricolpites stylidioides in laminated claystones and siltstones within and overlying the tillite at Lemonthyme Creek (Macphail et al. 1993) firnly links the establishment of the family in Tasmania with Cenozoic global cooling.

\section{Tricolporate Pollen}

GENUS Mutisiapollis n.gen.

TYPE SPECIES Mutisiapollis patersonii n.sp.

DERIVATION OF NAME. From the presumed botanical affinity with Mutisia L.f. (Asteraceae tribe Mutisieae).

DIAGNOSIS. Monad, isopolar, radiosymmetric; tricolporate, colpi long, endocolpi lalongate; subprolate-prolate, amb subcircular; exine $>4 \mu \mathrm{m}$ thick at equator, sexine clearly stratified with a basal layer of thick columellae separated by an internal tectal layer from an outer layer of short, fine columellae, rectum undulate, punctoreticulate, microechinate.

DISCUSSION. Mutisia is a moderate-sized genus of shrubs and lianes, more or less confined to the Andes in South America. Its pollen is said to be distinct from that produced by other genera within the tribe Mutisieae (Stix 1960) although transmission electron microscopy (Skvarla et al. 1977) has established that the pollen type falls within the Anthemoid pattern, also found within the tribes Anthemideae and Cynareae.

We are unawate whether fossil Mutisia-type pollen has been described from pre-Quaternary sediments in South America but note that Partridge (1978) referred a species of Tubulifloridites with well-developed echini, recovered from Late Tertiary sediments at DSDP Site 365 off the west coast of Africa, to Mutisia or Echinops (Cynareae).

Mutisiapollis patersonii n.sp., non Partridge, 1978, Fig. 12 (pl. 2, K-U)

DERIVATION OF NAME. After S.J. Paterson who, as Chief Geologist with the HEC, was responsible for the identification of Tertiary sediments at the Wilmot Dam site.

HOLOTYPE. Slide SB W-002, housed in the Department of Plant Science, University of Tasmania, England Finder co-ordinates S43(4); paratype at M29(2) on the same slide.

TYPE LOCALITY. HEC drillhole 5825, Lemonthyme Creek ( $\left.41^{\circ} 37^{\prime} \mathrm{S}, 146^{\circ} 09^{\prime} \mathrm{E}\right)$, at $101 \mathrm{fc}(30.8 \mathrm{~m})$, early Oligocene.

DIAGNOSIS. Monad, isopolar, radiosymmetric; tricolporate, colpi extending to near poles, endocolpi lalongate $c .5 \times 7 \mu \mathrm{m}$, oval to diamond-shaped, lateral margins often indistinct or ragged; exine $4-7 \mu \mathrm{m}$ thick at equator decreasing to $2.5-4 \mu \mathrm{m}$ at poles, nexine thinner than sexine but swelling to c. $3 \mu \mathrm{m}$ around endocolpi, sexine consisting of a basal layer of thick simplibaculate columellae $1.5-3 \mu \mathrm{m}$ long, separated by a homogeneous layer from an outer layer of fine columellae $<0.8 \mu \mathrm{m}$, surface of tectum often undulare in sectional view, appearing scabrate-verrucate in surface view due to subtectum structure, puncto-reticulate, microechinate.

DIMENSIONS Polar diameter 20-(36)-40 $\mu \mathrm{m}$, nine specimens measured; equatorial diameter $20-(27)-32 \mu \mathrm{m}$, eight specimens measured. 
DISTRIBUTION Northwestern Tasmania: Early to Middle? Oligocene; not recorded elsewhere to date.

DISCUSSEON Apart from variations in size, there is little to distinguish Mutisiapollis patersonii from pollen of Mutisia speciosa (fig. 62A in Erdtman 1966), M. decurrens and M. spectabilis (Heusser 1971: 30-31, pl. 23, figs 273, 274). Echinops is rambibaculate and lacks the secondary columellare layer in the subtectum (Erdtman 1966, fig. 64). Polupissusites SalardCheboldaeff emend. Pocknali, 1982 is rambibaculate and characterised by exine which thickens across the poles.

The records of Mutisiapollis patersonit are amongst the earliest for any member of the Asteraceae anywhere (see Muller 1981). Its Cenozoic distribution in Tasmania is similar to Cyatheacidites annulatus, in that both first appear during the Early Oligocene whilst the modern sources are now confined to South America. A logical explanation is that Antarctica was the centre of origin/ dispersal for both taxa.

\section{Periporate Pollen}

GENUS Periporopollenites Pflug \& Thomson, 1953

TYPE SPECIES Periporopollenites stigmosus Potonie, designated by Pflug \& Thompson in Thompson \& Pflug 1953

\section{Periporopollenites hexaporus n.sp. (pl. 3, A-J)}

1991 Unknown species Macphail et al: 96, fig. 5M-O

HOLOTYPE Slide SB W-003, stored in the Department of Plant Science, University of Tasmania: England Finder co-ordinates $\mathrm{R} 47(3)$; paratype at $\mathrm{X} 46(0)$ on the same slide.

TYPE LOCALITY HEC drillhole 5825, Lemonthyme Creek $\left(41^{\circ} 37^{\prime} \mathrm{S}, 146^{\circ} 09^{\prime} \mathrm{E}\right)$, at $102 \mathrm{ft}(31.1 \mathrm{~m})$, Early Oligocene.

DERIVATION OF NAME From the characteristic number of pores.

DIAGNOSIS Monad, apolar, sphaeroidal although often compressed into a cubical to polyhedrol shape; periporate, pores six, rarely 12, large, circular, 4-7 $\mu \mathrm{m}$, weakly annulate; exine 1.5 $2.5 \mu \mathrm{m}$ thick, sexine twice as thick as nexine, columellae coarse, clavate-gemmate, heads wholly or partially fused to form a thin tectum, puncto-reticulate.

DIMENSION 22-(25)-32 $\mu \mathrm{m}, 13$ specimens measured.

BOTANICAL AFFINITY Trimeniaceae?

DISTRIBUTION Northwestern Tasmania: Early Oligocene to Late Oligocene/Early Miocene; not recorded elsewhere to date.

DISCUSSION. Stover \& Partridge (1973: 272) have used Periporopollenites to accommodate fossil periporate pollen characterised by ten to approximately 32 simple apertures and exine that is clearly stratified and thin, relative to the size of the grain. In spite of the lower number of pores, relatively thick exine and verrucate sculpture, $P$. hexaporus appears to be related to $P$. demarcatus Stover \& Partridge, 1973 via intermediate forms (see below). For this reason we prefer to retain the species within
Periporopollenites rather than accommodate the type in Parsonsidites Couper, 1960 (erected to cover psilate to scabrate grains with five or more pores) or Polyporites Samoilovich \& Mtchedlishvili, 1961 (erected to cover grains with five to six pores and pilate exine).

Most populations of Periporopollenites hexaporus include specimens characterised by thin pilate columellate, semi-tectate exine (often corroded) and with 10 to 18 (av. 12) pores which may or may not be surrounded by annuli (pl. 3, K-M). Further work is required to assess whether this morphorype warranrs species status. At present, we prefer to regard it as an intermediate berween hexaporus and the demarcatus-vesicus complex (pl. 3, N-Q) and suggest that all species are part of the same (Trimeniaceaen?) phylogenetic lineage. If correct, the (to date) restriction of $P$. hexaporus to Tasmania is evidence of local evolution within this family.

\section{OTHER TAXA}

Trilete Spores

\author{
Cyatheacidites annulatus Cookson, 1947 (pl.1, A-D)
}

Spores with this morphology are now only found within the monospecific South American tree-fern family Lophosoriaceae.

The fossil taxon has a markedly disjunct time distribution in Australia: Cyatheacidites tectifera which first appears in the late Albian and becomes extinct in the Campanian, and C. annulatus which first appears in the early Oligocene and becomes extinct during the Pliocene. This almost certainly reflects two separate, ultimately unsuccessful colonisation events. Based on the variations in the morphology of the three raised pads on the proximal surface, several subspecies may have evolved within the C. annulatus lineage during the late Tertiary.

\section{Tricolpate Pollen}

Gothanipollis perplexus Pocknall \& Mildenhall, 1984 (pl. 5, A) Gothanipollis sp. cf G. gothanii Krutzsch, 1959 (pl. 4, B) Gothanipollis sp. of G. bassensis Stover \& Partridge, 1973 (pl. 5, C) Tricolpites simatus Stover \& Partridge, 1973 (pl. 5, D)

Although now extinct in Tasmania, Gothanipollis spp. and Tricolpites simatus show that Loranthaceae were part of the regional flora from the late Early Eocene into the Middle Pleistocene (Macphail et al. 1993c). Interestingly, the first appearance of Loranthaceae pollen in Tasmania is earlier and extinction of the type later than in the Gippsland Basin (compare Stover \& Partridge 1973).

\section{Tricolporate Pollen}

$$
\text { Margocolporites sp. of Anopterus (pl. 4, H-I) }
$$

This psilate tricolporate type broadly resembles modern Anopterus (Escalloniaceae) pollen in having strongly developed margo costae and pronounced endo-cracking of the exine. 

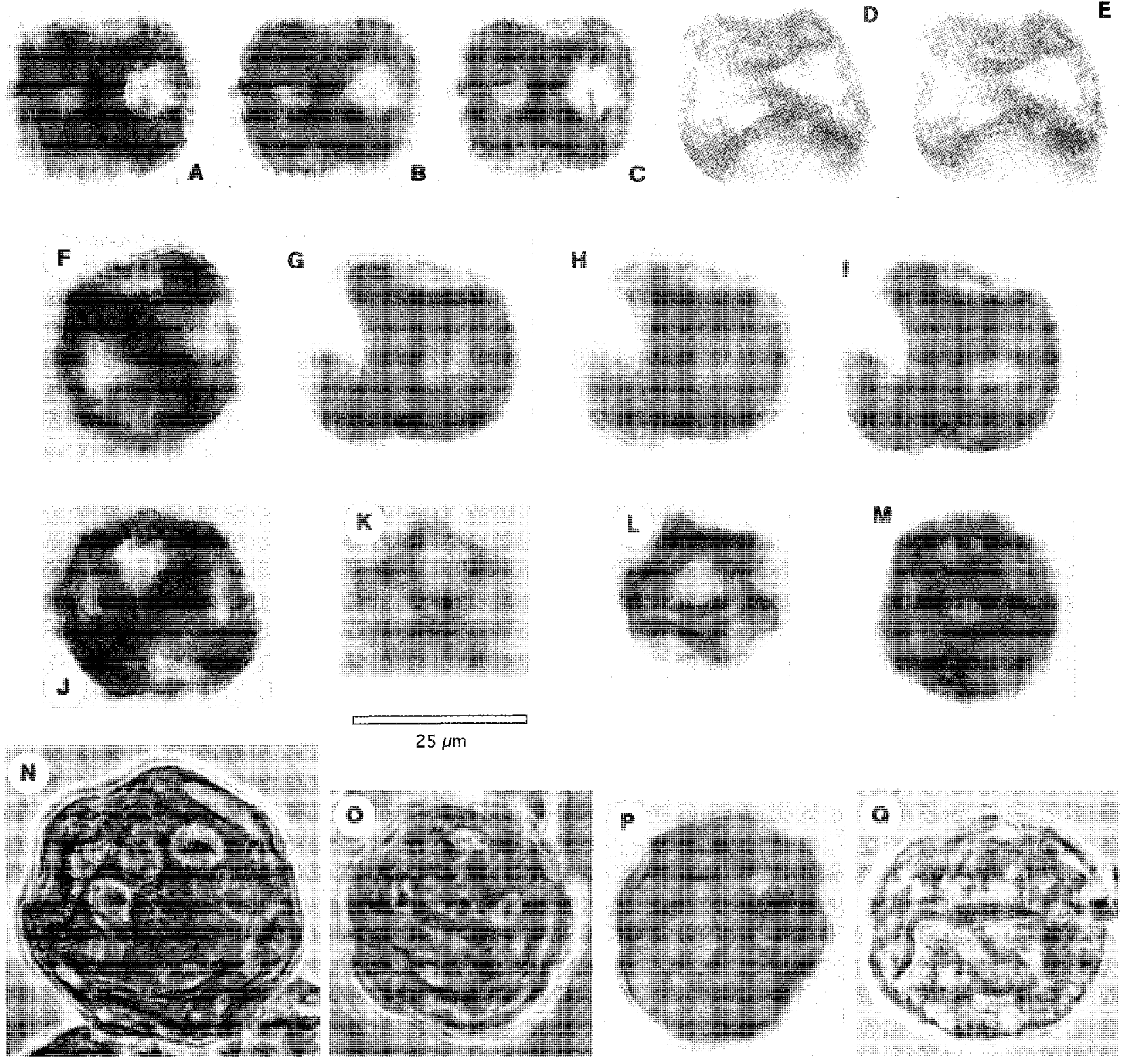

PLATE 3

New species (continued). All photomicrographs $\times 1250$ unless otherwise stated. Scale bar $A=25 \mu \mathrm{m}$; scale bar $B=50 \mu \mathrm{m}$.

Periporopollenites hexaporus n. sp. (A-C) Holotype at three focal planes; oblique view - Lemonthyme DH 5802 at $31.1 \mathrm{~m}$, P. tuberculatus Zone; $(D-E)$ paratype at two focal planes; oblique view-Lemonthyme DH 5825 at $31.1 \mathrm{~m}$, P. tuberculatus $Z$ one; (F) specimen showing strongly developed verrucate ornamentation - Lemonthyme DH 5802 at $46 \mathrm{~m}$, P. tuberculatus Zone; $(G-I)$ specimen showing (1) poroid split in nexinous membrane across pore and (2) fusion of clavate columellae to form a verrucate tectum - Wilmot Dam DH 4558 at $23.6 \mathrm{~m}$, P. tuberculatus Zone; (J) specimen showing clavate columellae more or less reduced to gemmae; semi-tectate - Lemonthyme DH 5802 at $46 \mu$, P. tuberculatus Zone; (K) specimen intermediate between P. hexaporus and $\mathrm{P}$. demarcatus; 12 pores present; columellae pilate; tectum thin, corroded; annuliabsent around pores - Lemonthyme DH 5825 at $36.6 \mathrm{~m}$, P. tuberculatus Zone; ( L) 10-porate grain with well developed annuli - Wilmot Dam DH 4558 at $23.6 \mathrm{~m}$, P. tuberculatus Zone; (M) 18-porate specimen with well-developed annuli-Lemonthyme DH 5802 at 46 m, P. tuberculatus Zone.

Periporopollenites demarcatus Stover \& Partridge, 1973. (N) Crushed, unusually large specimen; note puncto-reticulate tectum; phase contrast - Wilmot Dam DH 4558 at $21.3 \mathrm{~m}$, P. tuberculatus Zone; (O) as above; phase contrast - Lemonthyme DH 5825 at $36.6 \mathrm{~m}$, P. tuberculatus Zone.

Periporopollenites vesicus Stover \&́r Partridge, 1973. (P) Wilmot Dam DH 4558 at $21.3 \mathrm{~m}$, P. tuberculatus Zone.

Periporopollenites sp. cf. P. polyoratus (Couper) Stover \& Partridge, 1973. (Q) Lemonthyme DH 5825 at 31 .1 m, P. tuberculatus Zone. 
Tetraporate Pollen

Tetrapollis campbellbrownii Macphail \& Truswell 1993 (pl. 1, $\mathrm{H}-\mathrm{I})$

This species, first described from Oligocene-late Early Miocene sediments in the Murray Basin, is characterised by four (rarely three or five) pores surrounded by channeled nexine: columellae are not visible but the sexine is clearly stratified into two layers, the outermost of which tends to be undulate.

Although difficult to photograph, all features are displayed by the Wilmot Dam specimen. The species is widespread in Oligo-

\section{PLATE 4 (see next page)}

Woody taxa. All photomicrographs $\times 1250$ unless otherwise stated. Scale bar $A=25 \mu \mathrm{m}$; scale bar $B=50 \mu \mathrm{m}$. (A) Microcachrydites antarcticus Cookson, 1947 - Lemonthyme DH 5825 at $36.6 \mathrm{~m}$, P. tuberculatus Zone; (B) Podosporites erugatus Mildenhall, 1978 - Lemonthyme DH 5825 at $36.6 \mathrm{~m}$, P. tuberculatus Zone; (C) Nothofagidites flemingii (Couper) Potonié, 1960 Lemonthyme DH 5802 at 46 m, P. tuberculatus Zone; (D) Quintiniapollis psilatispora (Martin) Mildenhall \&o Pocknall, 1989 - Wilmot Dam DH 4558 at 21.3 m. P. tuberculatus Zone; (E) Sapotaceoidaepollenites latizonatus (McIntyre) Pocknall \& Mildenhall, 1984 - Wilmot Dam DH 4558 at $21.3 \mathrm{~m}$. P. tuberculatus Zone; (F-G) pentacolporate sp. Meliaceael?]; this type differs from five-pored specimens of $T$ etracolporites palynius Stover \& Partridge, 1982, in that the nexine is strongly thickened around the pores; polar view - (F) equatorial view; (G) Wilmot Dam DH 4558 at $21.3 \mathrm{~m}$, P. tuberculatus Zone; (H) Margocolporites sp. cf. Anopterus (Escalloniaceae). Polar view; note prominent margo colpae and pronounced endocracks in exine - Lemonthyme DH 5825 at 33.5 m, P. tuberculatus Zone; (I) as above; phase contrast - Lemonthyme DH 5825 at 33.5 m, P. tuberculatus Zone; (J) as above; equatorial view; it is uncertain whether the crossed longitudinal colpi are characteristic of the type - Lemonthyme DH 5825 at $29.3 \mathrm{~m}$, P. tuberculatus Zone; $(K)$ tetraporate sp. cf Tricolporites adelaidensis Stover \& Partridge, 1982; the specimen falls within the size and pore range but it lacks the gaping, short colpi characterising this species; Tetracol porites spectabilis Pocknall \&. Mildenhall is brevicolpate with annulate ora - Lemonthyme DH 5825 at $33.5 \mathrm{~m}$, P. tuberculatus Zone; (L-M) Tricolporites sp. cf. Muehlenbeckia (Polygonaceae); the species is characterized by the finely scabrate sculpture and diamond-shaped lalaongate endocolpi - Wilmot Dam DH 4588 at $23.6 \mathrm{~m}$, P. tuberculatus Zone; (N) Rhoipites (al. Tricolporites) microreticulatus Harris, 1965 - Wilmot Dam DH 4558 at 23.6 m, P. tuberculatus Zone; (O) Dryadopollis retequetrus (Stover \& Partridge), Pocknall \&. Mildenhall, 1984; $\times 788$ - Wilmot Dam DH 4558 at $21.3 \mathrm{~m}$. P. tuberculatus Zone; $(P)$ cf. Dryadopollis retequetrus (Stover \& Partridge), Pocknall \& Mildenhall, 1984; 788 - Wilmot Dam DH 4558 at $21.3 \mathrm{~m}$, P. tuberculatus Zone; (Q) Beaupreaidites elegansiformis Cookson, 1950; phase contrast - Lemonthyme DH 5802 at $46 \mathrm{~m}$, P. tuberculatus Zone; (R) Triporopollenites sp. cf. T. chnosus Stover \& Partridge, 1973; $\times 788$ - Wilmot Dam DH 4558 at $21.3 \mathrm{~m}$, P. tuberculatus Zone; (S) Malvacipollis subtilis; phase contrast - Lemonthyme DH 5825 at $31.1 \mathrm{~m}$, P. tuberculatus Zone. 

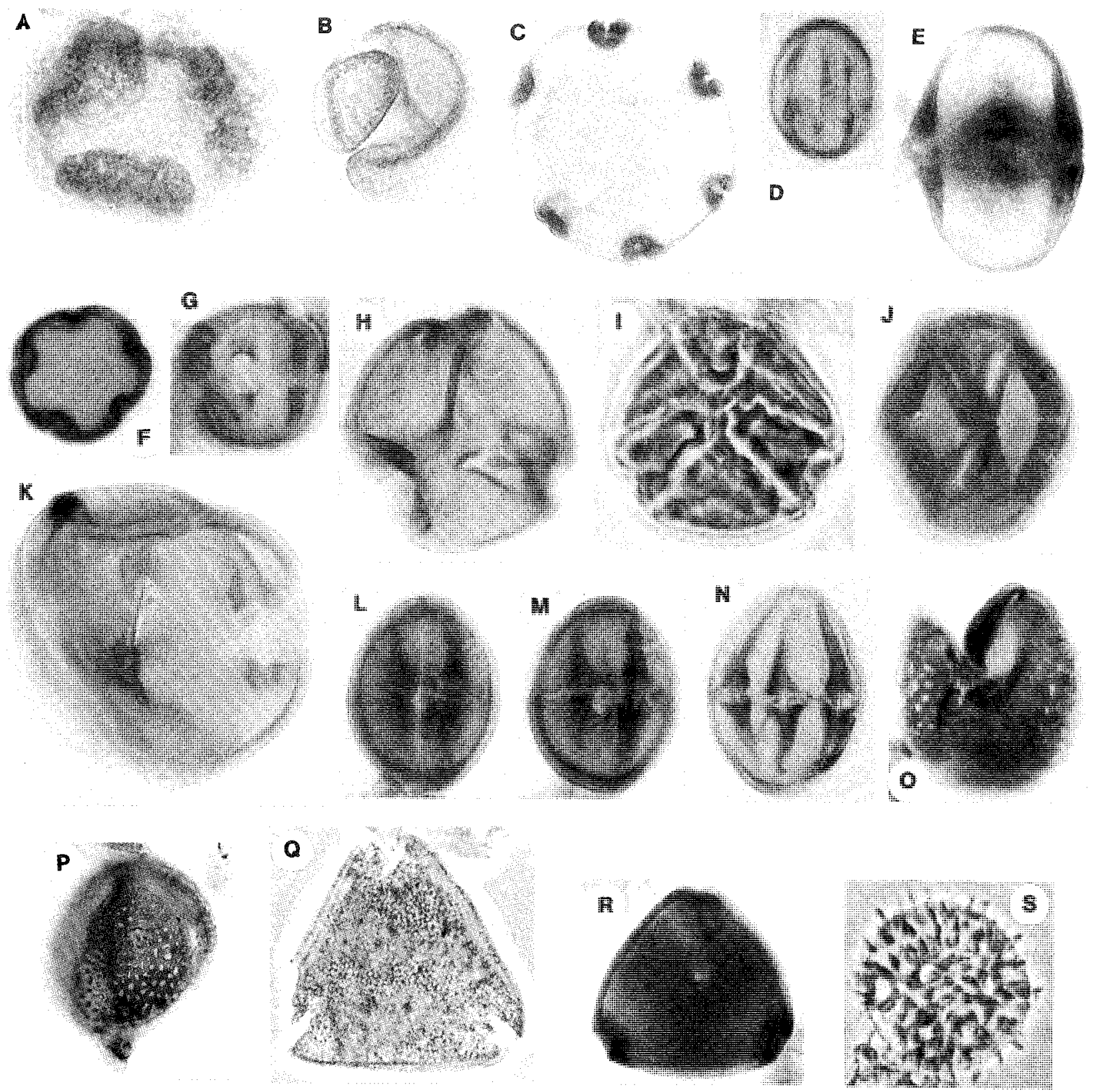

$50 \mu \mathrm{m}$

$\mathrm{O}, \mathrm{P}, \mathrm{R}$

$25 \mu \mathrm{m}$

A-N, Q, S 

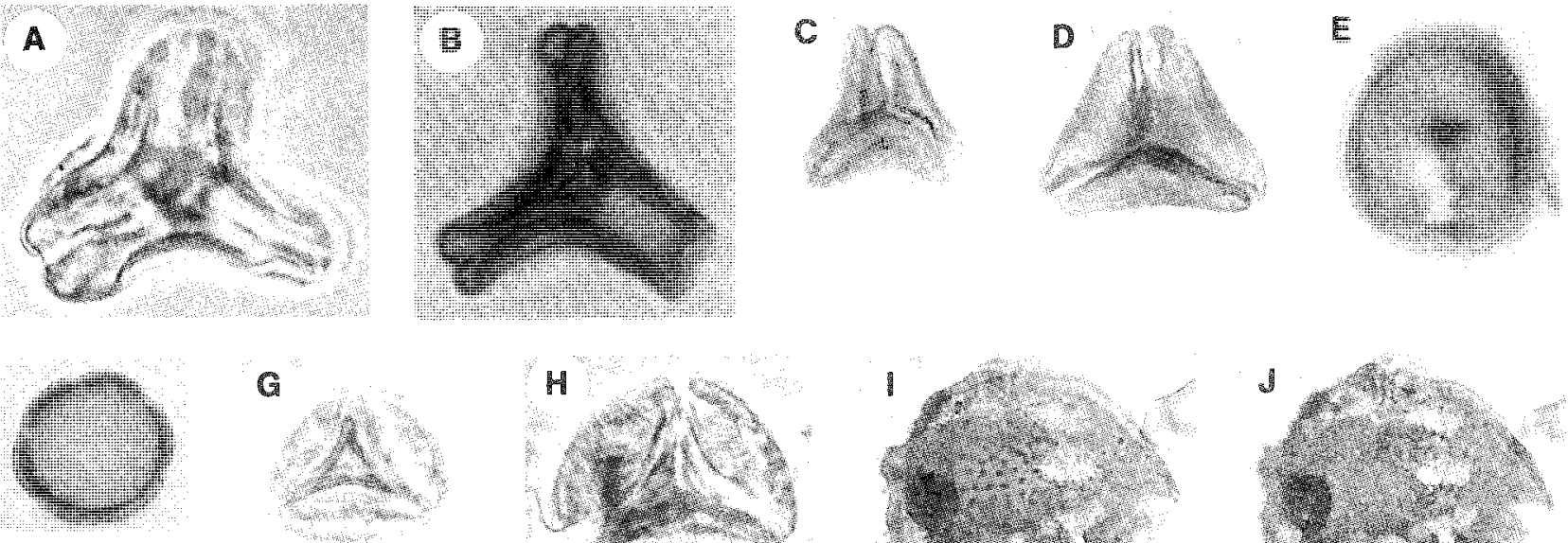

$\mathbf{F}$
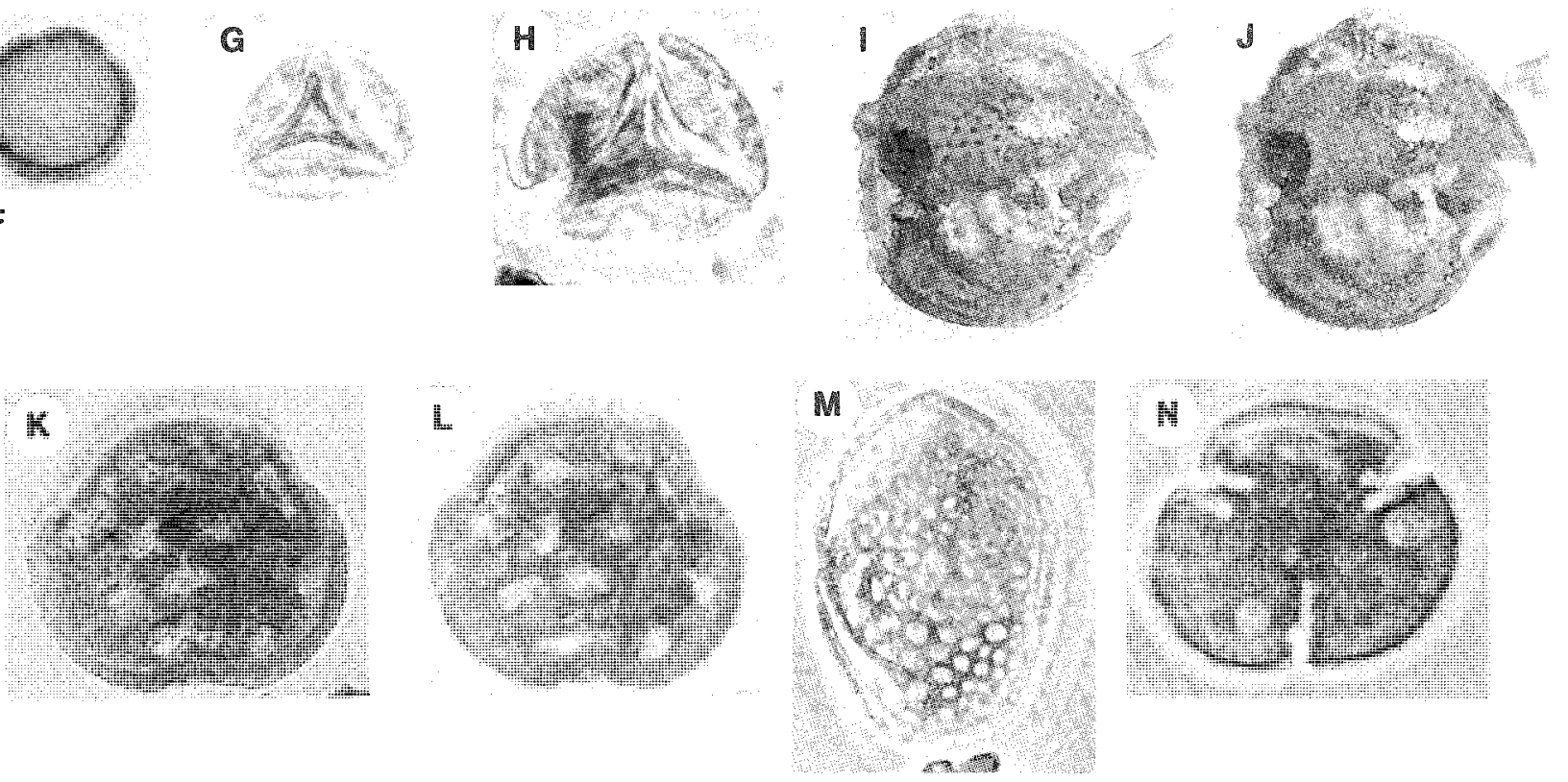

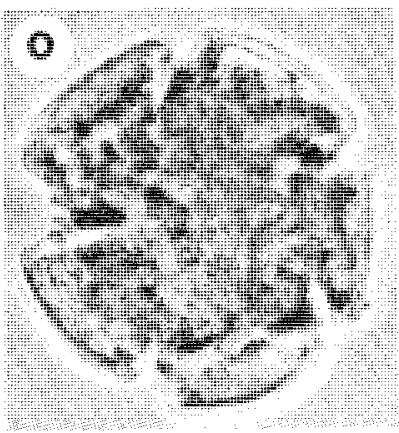

$50 \mu \mathrm{m}$

I-L, Q, R
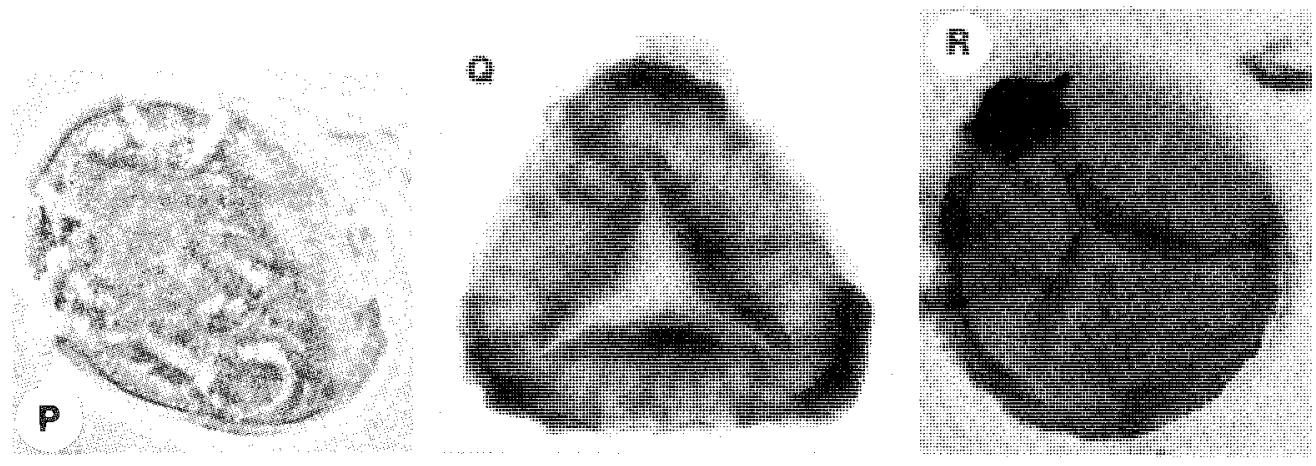

$25 \mu \mathrm{m}$

A-H, M-P

\section{PLATE 5}

Climbers, herbs, ferns and fern allies. (A) Gothanipollis perplexus Pocknall \& Mildenhall, 1984 - Lemonthyme DH 5825 at 39.9 m. P. tuberculatus Zone; (B) Gothanipollis sp. cf. G. gothani Krutzsch, 1959 - Wilmot Dam DH 4558 at 23.6 m, P. tuberculatus Zone; (C) Gothanipollis sp. cf. G. bassensis Stover \&.Partridge, 1973 - Wilmot Dam DH 4558 at $23.6 \mathrm{~m}$, P. tuberculatus Zone; (D) Tricolpites simatus Stover \& Partridge, 1973 - Wilmot Dam DH 4558 at $21.3 \mathrm{~m}$, P. tuberculatus Zone; (E) Tricolpites trioblatus Mildenhall \& Pocknall, 1989; equatorial view - Wilmot Dam DH 4558 at $23.6 \mathrm{~m}$, P. tuberculatus Zone; (F) Stephanocolpites oblatus Martin, 1973 - Wilmot Dam DH 4558 at 21.3 m, P. tuberculatus Zone; (G) Striasyncolpites laxus Mildenhall \& Pocknall, 1989; phase contrast - Lemonthyme DH 5825 at $29.3 \mathrm{~m}$, P. tuberculatus Zone; (H) Striasyncolpites laxus Mildenhall \& Pocknall, 1989; phase contrast_Lemonthyme DH 5825 at 29.3 m, P. tuberculatus Zone; ( I-J) Droseraceae; $\times 788$ _. Lemonthyme DH 5825 at $31.1 \mathrm{~m}$, P. tuberculatus Zone; (K-L) Droseraceae; $\times 788-$ Lemonthyme DH 5825 at $39.9 \mathrm{~m}$, P. tuberculatus Zone; (M) Liliacidites sp.; phase contrast - Wilmot Dam DH 4558 at $21.3 \mathrm{~m}$, P. cuberculatus Zone; $(N)$ Tricolpites reticulatus Cookson ex Couperemend. Jarzen \& Dettmann, 1989; phase contrast-Wilmot Dam DH 4558 at $23.6 \mathrm{~m}$, P. tuberculatus Zone; $(O)$ Retistephanocolpites sp. aff. Callitriche (Callitricheaceae) — Wilmot Dam DH 4558 at 23.6 m. P. tuberculatus Zone; (P) Stephanocolpites sphericus (Couper) Mildenhall \& Pocknall, 1989; phase contrast - Lemonthyme DH 5825 at 31.1 m, P. tuberculatus Zone; (Q) Ischyosporites (al. Klukisporites) lachlanensis Martin, 1973; $\times 788$ - Wilmot Dam DH 4558 at $21.3 \mathrm{~m}$, P. tuberculatus Zone; (R) Latrobosporites marginis Mildenhall \& Pocknall, 1989; $\times 788$ - Lemonthyme DH 5825 at $24.7 \mathrm{~m}$, P. tuberculatus Zone. 